\title{
THE CHARACTERISTICS OF THE OPERATING PARAMETERS OF THE VERTICAL AXIS WIND TURBINE FOR THE SELECTED WIND SPEED
}

\author{
Zdzisław Kamiński' ${ }^{1}$ Zbigniew Czyż \\ 1 Department of Thermodynamics, Fluid Mechanics and Aviation Propulsion Systems, Faculty of Mechanical \\ Engineering, Lublin University of Technology, 36 Nadbystrzycka Str., 20-618 Lublin, Poland, e-mail: \\ z.kaminski@pollub.pl, z.czyz@pollub.pl
}

Received: 2016.12 .15

Accepted: 2017.02.01

Published: 2017.03.01

\begin{abstract}
The article presents the results of examining a wind turbine on the vertical axis of rotation. The study was conducted in an open circuit wind tunnel Gunt HM 170 in the laboratory of the Department of Thermodynamics, Fluid Mechanics and Aviation Propulsion Systems at Lublin University of Technology. The subject of research was a rotor based on the patent PL 219985, with blades capable of altering the surface of the active area (receiving kinetic energy of the wind). The study was performed on appropriately scaled and geometrically similar models maintaining, relevant to the type of research, the criterion numbers. The studied rotors with different blade inclination angles were produced using a 3D powder printer ZPrinter ${ }^{\circledR} 450$. The results of the conducted research were obtained for the flow velocity of $6.5 \mathrm{~m} / \mathrm{s}$ and three inclination angles, $30^{\circ}, 60^{\circ}$, and $90^{\circ}$, at variable rotational speed. The test equipment used in the study allows maintaining the required speed, recording velocity and torque, which in turn allows an engineer to measure such characteristics of torque and power as a function of rotor speed.
\end{abstract}

Keywords: wind turbine, renewable energy, wind tunnel, drive torque, power.

\section{INTRODUCTION}

Wind energy is the energy that comes from the sun. The phenomenon of the wind is related primarily to the uneven heating of air masses by solar radiation, uneven surface of land and Earth's rotation. Conversion of kinetic energy derived from moving air masses into mechanical energy is done using a wind turbine or wind turbines complex. The energy produced in this way can be used to perform certain tasks (e.g. pumping water) or using a generator to produce electricity. First attempts to generate electricity using wind were undertaken in the nineteenth century, but only in recent years did this method start to be used on a larger scale. To use wind energy to generate electricity certain conditions must be met constant wind with definite speed. Wind turbines usually operate at wind speed rates of 5 to $25 \mathrm{~m} / \mathrm{s}$, and the speed of 15 to $20 \mathrm{~m} / \mathrm{s}$ is considered optimal. Inadequately low speeds are insufficient for the production of electric energy of adequate power, while too high ones (over $30 \mathrm{~m} / \mathrm{sec}$ ) can lead to mechanical damage to the rotor. The location of the wind power plant is also important because it must take into account the roughness of the terrain and the impact of natural obstacles on wind flow. Rotors should not be located in a turbulent area where air turbulence reduces efficiency of power stations and can furthermore disturb its construction. The average wind speed in Poland is $3.4 \mathrm{~m} / \mathrm{s}$ in the summer months, and $3.8 \mathrm{~m} / \mathrm{s}$ in the winter months. It is worth noting that the seasonal wind energy resources coincide quite well with the maximum demand for thermal energy, which is the period of the lowest temperatures [16]. Wind energy is an important, environmentally friendly source of energy, which has be- 


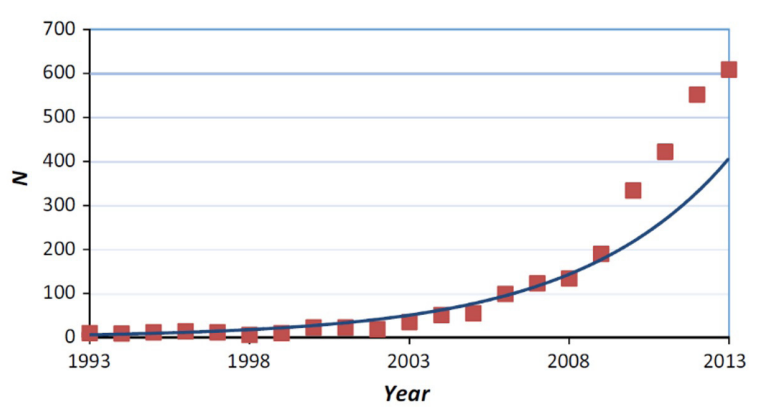

Fig. 1. The number of articles on optimization of wind turbines in the last 20 years $[4,9]$

come increasingly important in recent years. The number of wind turbines installed every year is growing, and a lot of countries plan to invest in wind power in the near future [29].

Harnessing wind power is generating considerable interest, modern wind turbines begin to sell electricity to power networks [18, 23]. A constantly growing interest in wind turbines also results from the rising number of scientific works published every year. In determining the actual power, wind power plants must consider the mechanics of incoming wind mass flow on the rotor, aerodynamics of rotor planes and the efficiency of the rotor $[10,19,32,33]$. The yield depends on the wind turbine power coefficient $\mathrm{Cp}$, which determines how much power stored in the flowing air is converted by the wind turbine. The theoretical maximum power factor is determined by what is referred to as Betz' limit and is equal to 0.59 for an idealised wind turbine [25]. The issue of increasing the efficiency of wind turbines is a highly complex problem connected with optimization. Researchers have developed a variety of tools, methods, algorithms and models to optimise wind turbines. On the base of Scopus the authors [4], [9] have shown an exponential growth in the number of articles which explicitly raise the subject of wind turbines optimization (Figure 1).

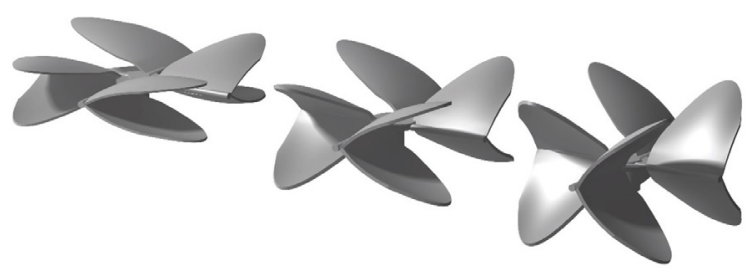

Fig. 2. 3D models of rotors of a wind turbine designed with an opening angle equal to the working surfaces, (from the left) $30^{\circ}, 60^{\circ}, 90^{\circ}$ respectively [6]
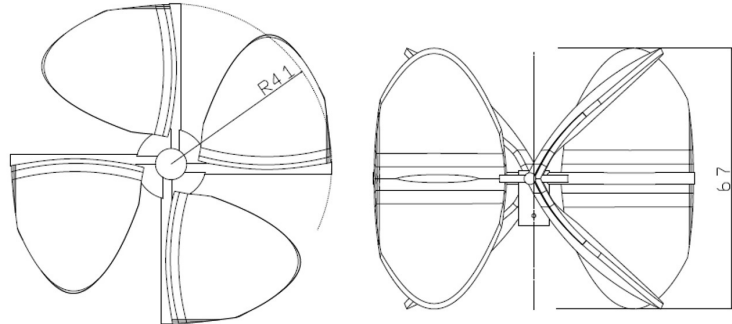

Fig. 3. Dimensions of the rotor (blade inclination angle $90^{\circ}$ )

The subject of optimization, and particularly the subject of reducing the cost of generation of energy (COE cost of energy) is referred to in $[1,2$, $4,7,8,11-15,17,22,24,27,34,35]$.

Currently, there are over 300 patents on various solutions regarding vertical-axis wind turbines (VAWT). The majority of those concern small power plants that can be used for the needs of individual customers. The main disadvantage of wind turbines with a vertical axis of rotation is virtually zero starting torque required for initial start-up. To eliminate this inconvenience numerous design modifications of turbines have been introduced, which were predominantly associated with the use of variable blade angles or the position of rotor blades [3]. An example of an innovative solution to eliminate the above drawbacks is the proposed vertical-axis model of adjustable working surface of rotor blades. This solution was granted a patent in the Polish Patent Office [31].

The testing of wind turbine with working surface inclination angles equal to $30^{\circ}, 60^{\circ}, 90^{\circ}$ were performed using CATIA v.5 (Fig. 2). Due to minimization of the research object conditioned by

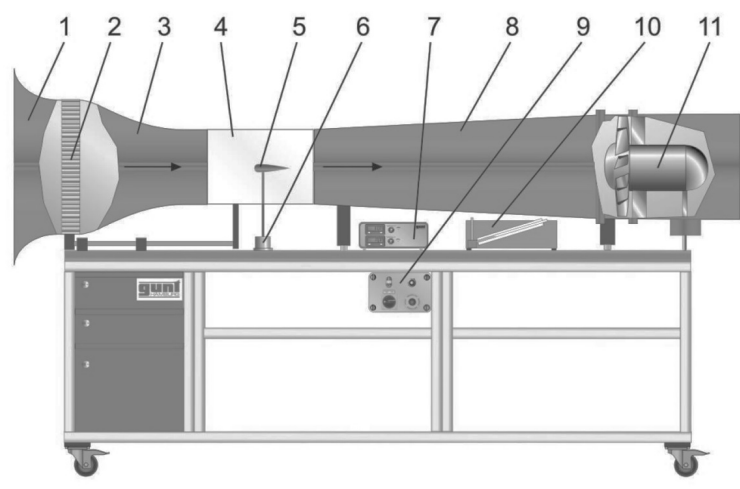

Fig. 4. Wind tunnel GUNT model HM 170, 1 - inlet contour, 2 - flow straightener, 3 - nozzle, 4 - measuring section, 5 - drag body, 6 - force sensor, 7 - display and control unit, 8 - diffuser, 9 - switch cabinet, 10 inclined tube manometer, 11 - axial fan [20] 
overall dimensions of the wind tunnel measuring space, it was decided to perform stable/permanent rotors (with $0^{\circ}$ blade inclination angle) in order to simplify the prototypes of test objects. Based on experience gathered in the construction of a model, it was established that the rotors will be produced on a powder printer ZPrinter ${ }^{\circledR} 450$. This is due to, inter alia, criteria of accuracy, aesthetics and execution time. Printed rotors were hardened with cyanoacrylate adhesive, and polished appropriately to give a smooth work surface. The applied technology is described in $[5,6]$.

Figure 3 shows dimensions of the rotor of a working surface inclination angle of $90^{\circ}$.

\section{TEST SET-UP}

Wind tunnel, often equipped in specialist measuring systems, constitutes a basic tool in experimental aerodynamics (Figure 4). Depending on the application, it allows to transfer the results of model tests to objects in the real scale, taking into account criteria of similarity and appropriate correction factors. The study used an open circuit tunnel, HM 170 GUNT, with a closed measurement space. Basic specifications of the tunnel are shown in Table 1. Such a system imposes limitations due to interference with the walls of the tunnel and the horizontal pressure gradient $\mathrm{dp} / \mathrm{dx}$. On the other hand, the advantage is reduced pressure pulsation and lower flow resistance. The use of the tunnel for testing consists in that the object tested is at rest while the air is set in motion, and thus the desired air flow around the model is generated by a fan placed inside. The air is sucked in from

Table 1. Basic parameters and their values characteristic of the wind tunnel GUNT model HM 170 [20]

\begin{tabular}{|l|c|}
\hline Parameter name or technical properties & Size parameter \\
\hline $\begin{array}{l}\text { The cross section of the test chamber } \\
\text { (width } x \text { height) }\end{array}$ & $292 \times 292 \mathrm{~mm}$ \\
\hline Length & $450 \mathrm{~mm}$ \\
\hline Maximum velocity of the air stream & $28 \mathrm{~m} / \mathrm{s}$ \\
\hline The pressure differential & $500 \mathrm{~Pa}$ \\
\hline Maksimum volume flow & $9000 \mathrm{~m}^{3} / \mathrm{h}$ \\
\hline Power of electric motor & $2.25 \mathrm{~kW}$ \\
\hline Maximum fan speed & $2850 \mathrm{obr} / \mathrm{min}$ \\
\hline Range of force measurement & $0-5 \mathrm{~N} \mathrm{i} \mathrm{0-10} \mathrm{N}$ \\
\hline Range of pressure measurement & $0-500 \mathrm{~Pa}$ \\
\hline
\end{tabular}

the atmosphere and accelerated in the converging channel 3 and then flows around the model in measuring section 4 . Behind the test chamber there is a diffuser 8 where the air speed is reduced and the air is pumped to the open air by the axial fan 11. A carefully designed outline of flow straightener ends 2 provides uniform velocity distribution with little turbulence in the closed measurement part. The built-in axial fan with a steering wheel and variable speed drive allows energy-efficient operation at high efficiency. Maximum air speed that can be generated in the wind tunnel is $28[\mathrm{~m} / \mathrm{s}]$.

The applied turbine testing system is shown in Figures 5 and 6 . Exchangeable rotors 4 are mounted to the vertical axis of turbine 2 (Figure $6)$. The outer part of the mast was modelled and printed on a $3 \mathrm{D}$ printer, and axis 2 (Figure 6) is made of carbon fibre and mounted on roller bearings. To the axis (below the measurement section) an electric DC motor 4 was mounted (Figure 6), acting as a brake.

Brake assembly is a major component of the test system of the wind turbine. The electric motor 4 (Figure 6) loads/charges the turbine rotor to produce torque opposite to the movement of rotor blades. The electric motor is fastened to a 50 -mm-long lever 5 which produces pressure on the strain gauge beam 6 (Figures 6 and 7).

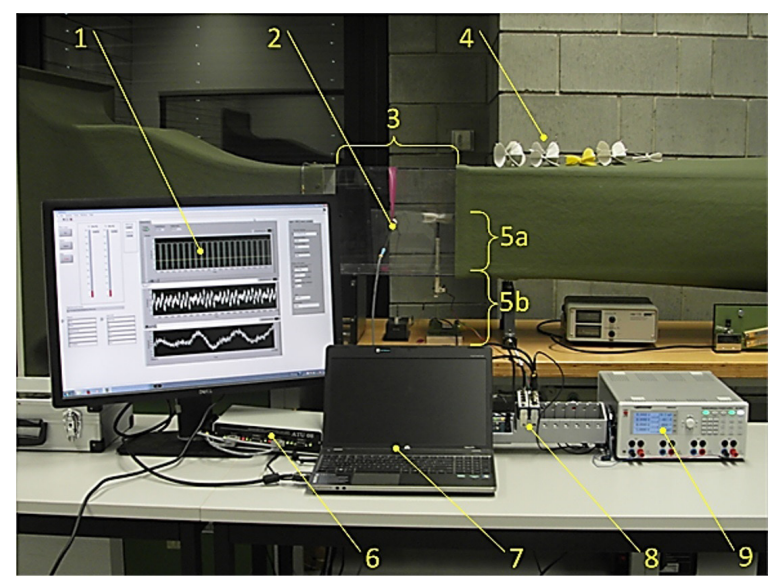

Fig. 5. The test turbine: 1 - data recording, 2 - a set of thermo-anemometric sensors, 3 - wind tunnel measuring space, 4 - a set of examined rotors of wind turbine, $5 \mathrm{a}$ - wind turbine assembly, $5 \mathrm{~b}$ - brake assembly of the turbine, $6-$ a unit managing thermoanemometers ATU-08, 7 - PC, 8 - Compact DAG Slot USB Chassis NI CDAG-9178 with measuring cards: NI 9215 (measuring the rotational speed of the rotor turbine), NI 9237 (force measurement), 9 - laboratory power supply R \& S®HMP4040 


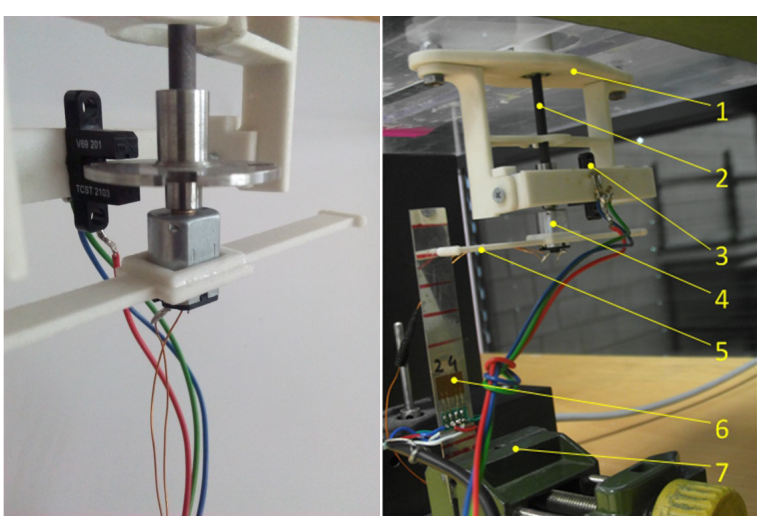

Fig. 6. Wind turbine brake set: 1- supporting structure of the turbine, 2- the turbine vertical axis turbine 3- optical sensor for rotational speed measurement 4- electric motor loading the turbine, 5- lever exerting force on the strain gauge, 6 - foil strain gauges stuck on the beam 7- the strain gauge handle

The strain gauge beam is composed of 0.5 $\mathrm{mm} \times 15 \mathrm{~mm}$ steel sheet, with attached four foil strain gauges TENMEX TF3 / 120-W [20] stuck to it, and is shown in Figure 7 and Table 2.

The turbine brake set cooperates with a computer-aided processing of measurementcontrol data. Measurement signals are acquired by means of the system consisting of National Instruments Compact DAQ 9172 chassis with NI 9215 (rotational speed measurement of the turbine rotor performed with RMS) and NI 9237 measurement cards (force measurement) shown in Fig. 8, and a netbook with data recording and processing software.

Data acquisition and pre-processing was carried out using measurement software and software for test results analysis. Both programmes were executed in LabVIEW 8.1 (Laboratory Virtual Instrument Engineering Workbench), which is a product of National Instruments Corporation. LabVIEW is a programming environment for creating personalised utility programmes, such as Borland C, Borland Pascal etc. The main difference is the way the source code of the pro-

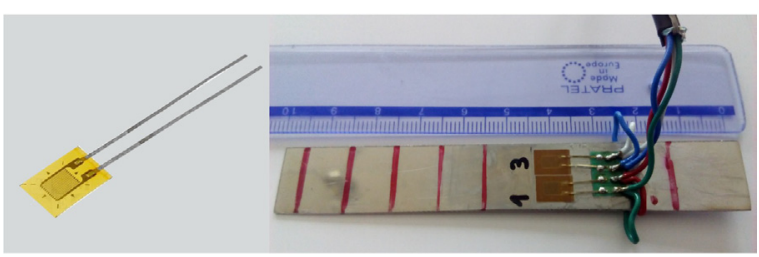

Fig 7. Foil strain gauge TENMEX TF3 / 120-W [21] and a strain gauge beam
Table 2. The characteristics of a foil strain gauge TENMEX TF3 / 120-W

\begin{tabular}{|l|c|}
\hline Sensor type & Strain gauge foil \\
\hline Working temperature & $-40 \div 200^{\circ} \mathrm{C}$ \\
\hline Properties of sensors & constant strain gauge 2.15 \\
\hline External dimensions & $5 \times 7.5 \times 0.06 \mathrm{~mm}$ \\
\hline Max. deformation & $5 \%$ \\
\hline Tolerance & $\pm 0.5 \%$ \\
\hline Terminal & silver pin \\
\hline Resistance & $120 \Omega$ \\
\hline
\end{tabular}

Table 3. Characteristic data of measurement card NI 9215 [26]

\begin{tabular}{|l|c|c|}
\hline Measurement conditions & Gain error & $\begin{array}{c}\text { Compensation } \\
\text { error }\end{array}$ \\
\hline Calibrated max. $\left(-40 \div+70^{\circ} \mathrm{C}\right)$ & $0.2 \%$ & $0.082 \%$ \\
\hline Calibrated type $\left(25 \pm 5^{\circ} \mathrm{C}\right)$ & $0.2 \%$ & $0.014 \%$ \\
\hline $\begin{array}{l}\text { Not calibrated max. }(-40 \div \\
\left.+70^{\circ} \mathrm{C}\right)\end{array}$ & $1.05 \%$ & $0.082 \%$ \\
\hline Not calibrated type $\left(25 \pm 5^{\circ} \mathrm{C}\right)$ & $0.6 \%$ & $0.38 \%$ \\
\hline
\end{tabular}

Table 4. Characteristic data of measurement card NI 9237 [26]

\begin{tabular}{|l|c|c|}
\hline \multicolumn{1}{|c|}{ Measurement conditions } & Gain error & $\begin{array}{c}\text { Compensation } \\
\text { error }\end{array}$ \\
\hline Calibrated max. $\left(-40 \div+70^{\circ} \mathrm{C}\right)$ & $0,20 \%$ & $0,25 \%$ \\
\hline Calibrated type $\left(25 \pm 5^{\circ} \mathrm{C}\right)$ & $0,05 \%$ & $0,05 \%$ \\
\hline Not calibrated max. $\left(-40 \div+70^{\circ} \mathrm{C}\right)$ & $0,60 \%$ & $0,35 \%$ \\
\hline Not calibrated type $\left(25 \pm 5^{\circ} \mathrm{C}\right)$ & $0,20 \%$ & $0,1 \%$ \\
\hline
\end{tabular}

gramme is created. In other environments, the source code is a sequential text representation in a specific programming language (Basic, $\mathrm{C}$, Pascal), while in LabVIEW the source code comes down to graphic representation of the input function (from keyboard and instruments), output (screen, printer and instruments), transferring and processing information, and the con-
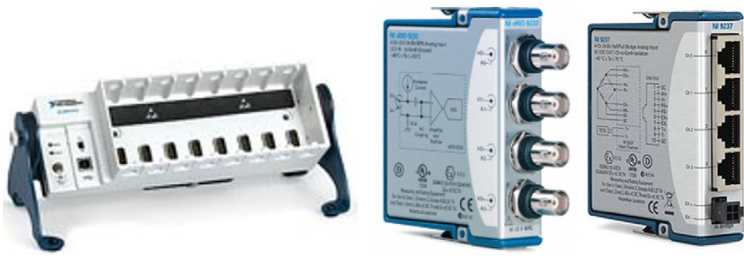

Fig. 8. Chassis National Instruments Compact DAQ 9172 with measurement cards NI 9215 and Ni 9237 [26] 


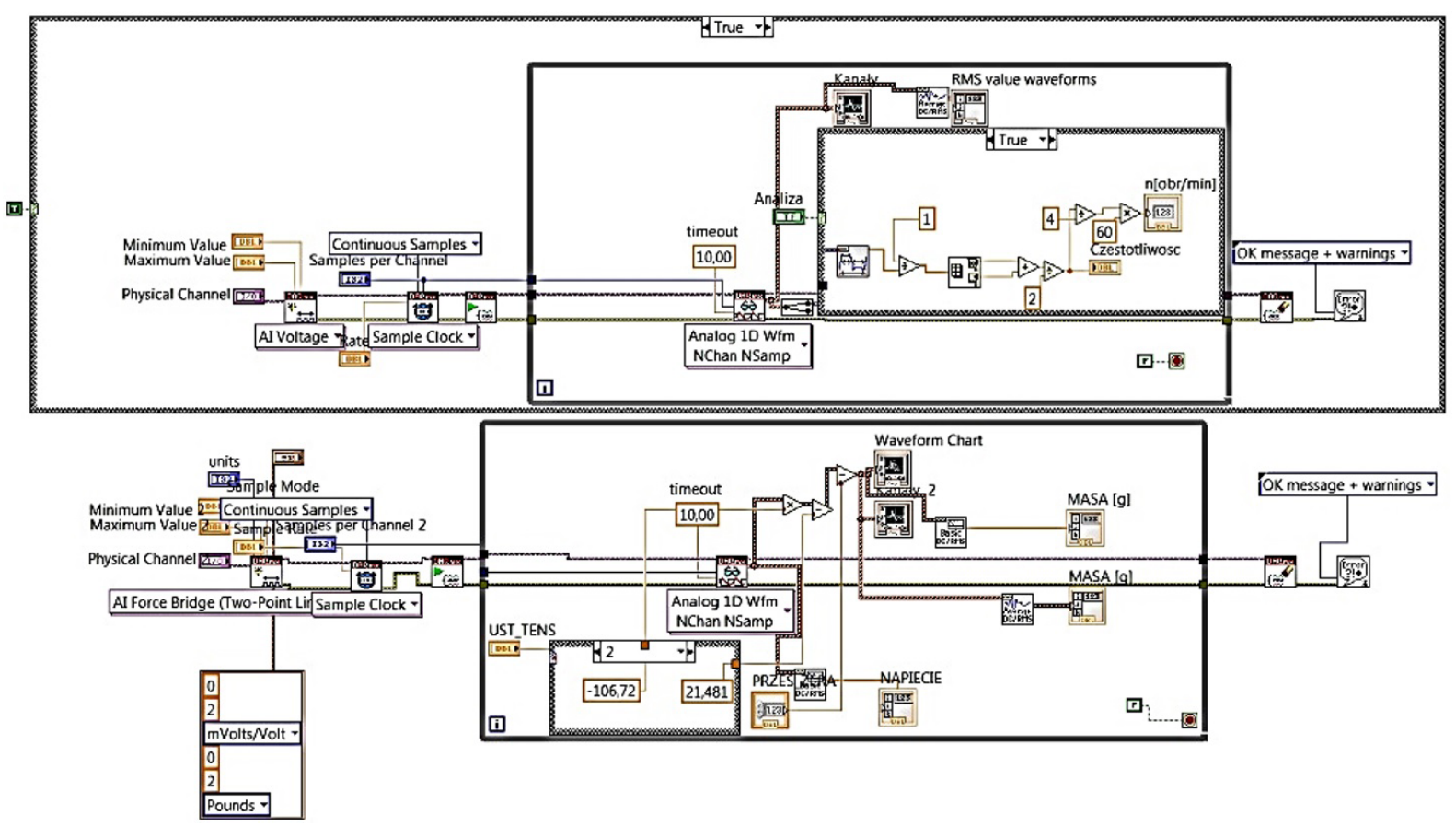

Fig. 9. Block diagram of data measurement and recording software

nection between blocks. Graphic language $G$ shows the recording of the program in the form of icons, clamps and connections, through which virtually any gauge can be built. Depending on your needs and the software, it can be a virtual oscilloscope, spectrum analyser, recorder, multimeter or any other type of device.

LabVIEW has an extensive library of functions and subprograms for most programming tasks. Moreover, it includes a rich library of software drivers for various measuring instruments, interface drivers GPEB, VXI and serial and function libraries for the collection, analysis and presentation of data. LabVIEW, as well as other programming environments, gives many

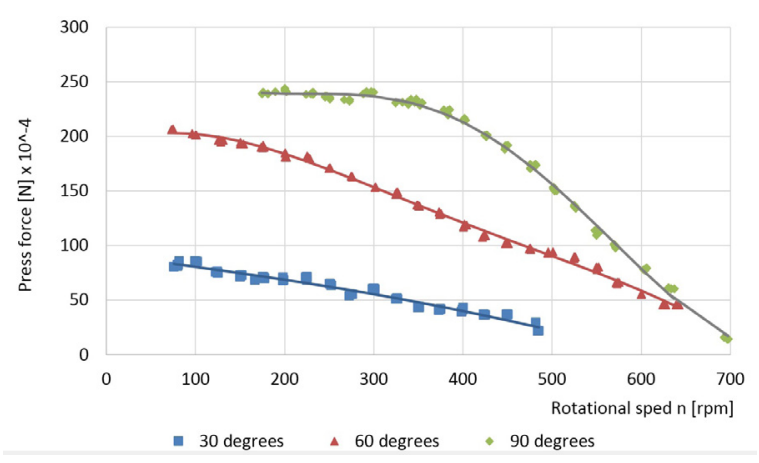

Fig. 10. Lever pressure on the strain gauge beam as a function of rotational speed for the examined angles of working blades possibilities to run the programme in search of errors. The software allows an engineer to set traps, animate the diagram of information flow, as well as run the programme step by step, in order to track the results in different parts of the programme $[28,30]$. A view of the block diagram of the programme for recording measurement data is shown in Figure 9.

\section{RESULTS}

Figure 10 presents the characteristics of lever pressure on the strain gauge beam as a function of speed for wind velocity equal to $6.5 \mathrm{~m} / \mathrm{s}$.

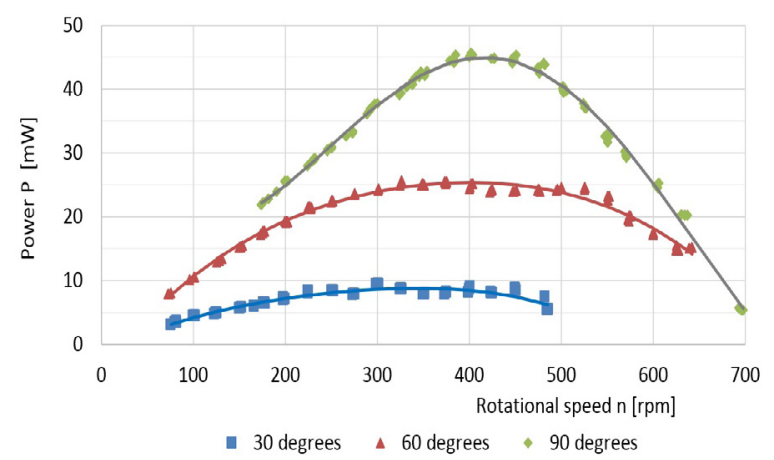

Fig. 11. Power characteristics of the test turbine rotor as a function of rotational speed for examined angles of working blades 
Test measurement points obtained during the research are approximated by the least squares method by means of Approximation v1.5.9.2 programme. As a result $4^{\text {th }}$ degree polynomials shown below were obtained, respectively for tested working surface inclination angles of the rotor turbine, i.e. $30^{\circ}, 60^{\circ}$ and $90^{\circ}$. The chosen degree of the polynomial is the one producing the least errors.

$$
\begin{gathered}
\mathrm{F}_{30}=\mathrm{F}_{30}(\mathrm{n})=3,83886103864611 \mathrm{E}-10 \cdot \mathrm{n}^{4}-5,13140787635671 \mathrm{E}-7 \cdot \mathrm{n}^{3} \\
+0,000137710478732145 \cdot \mathrm{n}^{2}-0,128905892843642 \cdot \mathrm{n}^{1}+92,6091338495036 \cdot \mathrm{n}^{0} \\
\mathrm{~F}_{60}=\mathrm{F}_{60}(\mathrm{n})=-2,79984594380679 \mathrm{E}-9 \cdot \mathrm{n}^{4}+4,54993308532521 \mathrm{E}-6 \cdot \mathrm{n}^{3} \\
-0,00264932926795291 \cdot \mathrm{n}^{2}+0,335491632864947 \cdot \mathrm{n}^{1}+191,420547278695 \cdot \mathrm{n}^{0} \\
\mathrm{~F}_{90}=\mathrm{F}_{90}(\mathrm{n})=9,97050177669547 \mathrm{E}-9 \cdot \mathrm{n}^{4}-1,59095357559089 \mathrm{E}-5 \cdot \mathrm{n}^{3} \\
+0,00776435915542609 \cdot \mathrm{n}^{2}-1,53073906112335 \cdot \mathrm{n}^{1}+346,316994093761 \cdot \mathrm{n}^{0}
\end{gathered}
$$

The torque $\mathrm{M}$ of turbine rotor was determined from the equation (4):

$$
M=F^{*} \mathrm{r}
$$

where: $\mathrm{M}$ - torque $[\mathrm{Nm}]$; F- force on the strain gauge $[\mathrm{N}]$; $\mathrm{r}$ - radius of force $\mathrm{F}[\mathrm{m}]$.

The power $\mathrm{P}$ generated by the turbine rotor was determined from the equation (5):

$$
P=\frac{M * n}{9550} * 10^{6}
$$

where: $\mathrm{P}$ - power generated by the rotor [ $\mathrm{mW}] ; \mathrm{n}$ - rotor speed $[\mathrm{r} / \mathrm{min}]$.

Below you can see characteristics of the power of the test turbine rotor as a function of rotational speed for the three angles of working blades, respectively: $30^{\circ}, 60^{\circ}, 90^{\circ}$.

$$
\begin{gathered}
\mathrm{P}_{30}=\mathrm{P}_{30}(\mathrm{n})=-4.6393220204193 \mathrm{SE}-10 \cdot \mathrm{n}^{4}+4.58900150626661 \mathrm{E}-7 \cdot \mathrm{n}^{3} \\
-0.000237719732272211 \cdot \mathrm{n}^{2}+0.0760979181168856 \cdot \mathrm{n}^{1}-1.41262596576373 \cdot \mathrm{n}^{0} \\
\mathrm{P}_{60}=\mathrm{P}_{60}(\mathrm{n})=-4.29813812920552 \mathrm{E}-10 \cdot \mathrm{n}^{4}+6.08578392385269 \mathrm{E}-7 \cdot \mathrm{n}^{3} \\
-0.000465184990199032 \cdot \mathrm{n}^{2}+0.190227702685209 \cdot \mathrm{n}^{1}-4.21801339864675 \cdot \mathrm{n}^{0} \\
\mathrm{P}_{90}=\mathrm{P}_{90}(\mathrm{n})=2.69486778935756 \mathrm{E}-9 \cdot \mathrm{n}^{4}-4.81178368174605 \mathrm{E}-6 \cdot \mathrm{n}^{3} \\
+0.00258607612024464 \cdot \mathrm{n}^{2}-0.428357438534595 \cdot \mathrm{n}^{1}+41.2989304374826 \cdot \mathrm{n}^{0}
\end{gathered}
$$

On the basis of the characteristics of the test turbine power as a function of rotor rotational speed for the investigated blade angles (Figure 11), maximum values of the power generated in the tested range were set. This makes it possible to chart the generated power as a function of the rotor working blades inclination angle. Figure 12 shows the effect of inclination angle on the generated power. $(0,0)$ was added to the points obtained in the test characteristic point to define a zero value of the full closure of working blades (inclination angle $0^{\circ}$ ) because of zero rotor working surface inclination.

The dependence of the effect of the blade inclination angle and the value of power generated is described by the equation 9 .

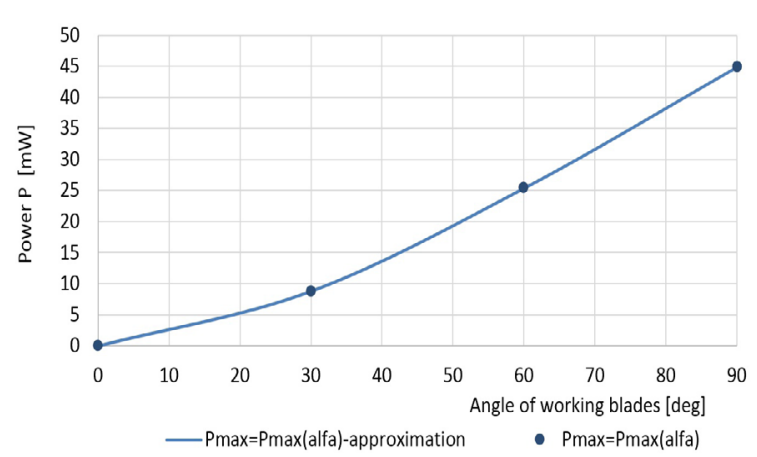

Fig. 12. Power of the test turbine as a function of blade inclination angle

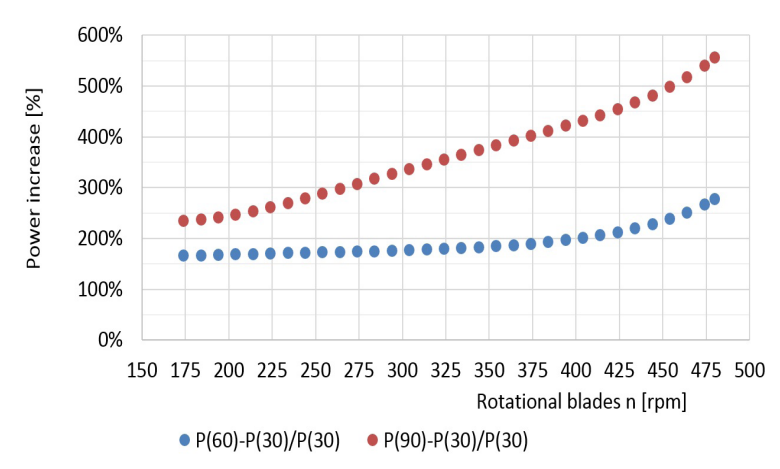

Fig. 13. The increase in power generated by the blade angle of $60^{\circ}$ and $90^{\circ}$ relative to the blade angle of $30^{\circ}$ 


$$
\begin{gathered}
\mathrm{P}=\mathrm{P}(\alpha)=-2,9876543209877 \mathrm{E}-5 \cdot \mathrm{n}^{3}+0,00700555555555562 \cdot \mathrm{n}^{2} \\
\quad+0,110388888888886 \cdot \mathrm{n}^{1}+1,89852340524411 \mathrm{E}-14 \cdot \mathrm{n}^{0}
\end{gathered}
$$

Figure 13 shows the increase in power generated exhibited at rotor inclination angles $60^{\circ}$ and $90^{\circ}$ compared to the blade inclination angle of $30^{\circ}$.

\section{CONCLUSIONS}

Test results, based on the functions approximating power depending on the speed of rotation, indicate that the rotor at an inclination angle of $30^{\circ}$ reaches maximum speed $\mathrm{n}_{\max }$ $=480 \mathrm{rpm}$ at a wind speed $\mathrm{v}=6.5 \mathrm{~m} / \mathrm{s}$. At this speed (idling) the rotor generates power of 6.4 $\mathrm{mW}$. During braking, the rotor has reached maximum power equal to $8.81 \mathrm{~mW}$ at a speed $\mathrm{n}=350 \mathrm{rpm}$. With reference to the minimum value of power generated by the rotor the result shows an increase of $278 \%$ (in the tested range). Further braking the rotor below the speed $\mathrm{n}=$ $350 \mathrm{rpm}$ reduces the power. Measurements of rotor inclination angle of $30^{\circ}$ were carried out at the rotational speed $\mathrm{n}_{\min }=81.7 \mathrm{rpm}$, at which the obtained power equals to $3.45 \mathrm{~mW}$.

The rotor with inclination angle of $60^{\circ}$ reaches the maximum speed $\mathrm{n}_{\max }=641 \mathrm{rpm}$ at a wind speed $\mathrm{v}=6.5 \mathrm{~m} / \mathrm{s}$. At this speed (idling) the rotor generates power at the level of 14.27 $\mathrm{mW}$. During braking, the rotor has reached the maximum power equal to $25.39 \mathrm{~mW}$ at the speed $\mathrm{n}=401 \mathrm{rpm}$. With reference to the minimum value of the power generated by the rotor it exhibits an increase of $342.9 \%$ (in the tested range). Further braking the rotor below the speed $\mathrm{n}=401 \mathrm{rpm}$ reduces the power. Measurements of rotor inclination angle of $60^{\circ}$ to the rotational speed were carried out to rotational speed $\mathrm{n}_{\min }=73.7 \mathrm{rpm}$ when the power equals to $7.5 \mathrm{~mW}$.

The rotor with inclination angle of $90^{\circ}$ reaches the maximum speed $n_{\max }=696 \mathrm{rpm}$ at the wind speed $\mathrm{v}=6.5 \mathrm{~m} / \mathrm{s}$. At this speed (idling) the rotor generates power of $5.98 \mathrm{~mW}$. During braking, the rotor has reached the maximum power equal to $44.9 \mathrm{~mW}$ at the speed $\mathrm{n}$ $=426.46 \mathrm{rpm}$. With reference to the minimum value of power generated by the rotor it denotes an increase of $792.6 \%$ (in the tested range). Further braking the rotor below the speed $\mathrm{n}=$ $426.46 \mathrm{rpm}$ reduces the power. Measurements of rotor inclination angle of $90^{\circ}$ were carried out to the speed $\mathrm{n}_{\min }=174 \mathrm{rpm}$, the obtained power equals to $22.1 \mathrm{~mW}$.
The evidence from this study implies that depending on the inclination angle of the working blades, it is possible to adjust the value of power input in the range of $0 \mathrm{~mW}$ (with blades fully closed) to $44.9 \mathrm{~mW}$ with inclination angle of the working blades of $90^{\circ}$. The mechanism of adjusting the inclination angle of working blades allows for smooth shift of the angle and simultaneously smooth change of power generated.

Our findings show that the larger the inclination angle the higher values of rotational speed are achieved. In order to make a comparative analysis of the results for different angles of inclination, only the speed range of $174 \mathrm{rev} / \mathrm{min}$ to $480 \mathrm{rev} / \mathrm{min}$ was taken into account. These values correspond respectively to the minimum rotational speed recorded for $90^{\circ}$ and the maximum speed value recorded for $30^{\circ}$ (Fig.11). If we increase the inclination angle in the specified speed range from $30^{\circ}$ to $60^{\circ}$, then the increase in the power generated will amount to $166 \%$ in the initial range and constantly growing with the rotational speed, until the end of the range where the power will increase by $277 \%$.

If, however, the inclination angle increases from $30^{\circ}$ to $90^{\circ}$, then at the initial range the power will increase by $235 \%$ and growing with rotational speed at the end of the range, the power will increase by $556 \%$.

Rotor blades with adjustable positions of blades allow the power of the turbine to be regulated over a wide range of values (of the main shaft or of the turbine) depending on wind speed and direction. This advantage prevents the destruction of components of the turbine in the event of high winds. This form of protection allows keeping a unit of turbine rotor in continuous operation and keeps the speed constant, which is important from the point of view of operating an electric generator. This makes it possible to obtain a constant value of power generated regardless of changes in wind speed (within a specified range) or it can work at optimum points, i.e. where the greatest amount of energy can be produced. 


\section{REFERENCES}

1. Al-Bahadly I. Wind Turbines. Springer- Verlag Berlin Heidelberg 2012.

2. Arroyo A, Manana M, Gomez C, Fernandez I, Delgado F, Zobaa AF. A methodology for the low-cost optimisation of small wind turbine performance. Appl Energy 2013;104:1-9.

3. Boczar T. Energertyka wiatrowa - aktualne możliwości I wykorzystania. Wydawnictwo PAK, W-wa 2008.

4. Chehouri A, Younes R, Ilinca A, Perron J. Review of performance optimization techniques applied to wind turbines. Applied Energy 142 (2015) 361-388.

5. Czyż Z, Kamiński Z. Badania symulacyjne wirnika turbiny wiatrowej o regulowanej powierzchni roboczej. Nowe trendy w naukach inżynieryjnych 3, Redakcja: dr. inż. M. Kuczera,Tom II, Creative Science, Monografia 2012, Creativetime, Kraków 2012, strony $243-251$.

6. Czyż Z, Kamiński Z. Badania wirnika turbiny wiatrowej o regulowanym położeniu łopat roboczych. Młodzi naukowcy dla polskiej nauki. Cz.7: Nauki inżynieryjne. T. 1; Redakcja: Kuczera Marcin - Kraków: 2012, s. 189-195.

7. Diveux T, Sebastian P, Bernard D, Puiggali J, Grandidier J. Horizontal axis wind turbine systems: optimization using genetic algorithms. Wind Energy 2001; 4:151-71.

8. Eke G, Onyewudiala J. Optimization of wind turbine blades using genetic algorithm. Global J Res Eng 2010:10.

9. Elsevier BV. <http://www.scopus.com/source/eval. url>. Scopus Journal Analyzer; 2014.

10. Flaga A. Siłownie wiatrowe, Wydawnictwo PK, Kraków 2012.

11. Fuglsang P, Aagaard Madsen H. Numerical optimization of wind turbine rotors. In: 1996 European wind energy conference and exhibition; 1996. p. 679-82.

12. Fuglsang P, Bak C, Schepers J, Bulder B, Cockerill T, Claiden P, et al. Site specific design optimization of wind turbines of 1.5-2.0 MW wind turbines. Wind Energy 2002;5:261-79.

13. Fuglsang P, Madsen HA. Optimization method for wind turbine rotors. J Wind Eng Ind Aerod 1999; 80:191-206.

14. Giguere P, Selig MS. Blade geometry optimization for the design of wind turbine rotors. In: Proceedings of AIAA/ASME wind energy symposium. Reno (Nevada); 2000.

15. Giguère $P$, Tangler J, Selig M. Blade design tradeoffs using low-lift airfoils for stall-regulated HAWTs. J SolEnergy Eng 1999;121:217-23.

16. Gumuła S. i in. Energetyka wiatrowa, Uczelniane
Wydawnictwa Naukowo- Dydaktyczne, Kraków 2006.

17. Hendriks H, Schepers G, Engelen Tv, Stern A, Boerstra G. Aeroelastically optimised cost efficient wind turbine: a case study. Netherlands Energy Research Foundation ECN; 1996.

18. Jastrzębska G. Odnawialne źródła energii i pojazdy proekologiczne. WNT, Warszawa 2009.

19. Jagodziński W. Silniki wiatrowe. PWT, Warszawa 1959.

20. Katalog Fluid mechanics \& hydrology, G.U.N.T. Geratebau GmbH, Hamburg, 2010.

21. Katalog produktów TENMEX Pracownia Tensometrii Elektrooporowej, S.C., Łódź,2015.

22. Kenway G, Martins J. Aerostructural shape optimization of wind turbine blades considering sitespecific winds. In: Proc of 12th AIAA/ISSMO multidisciplinary analysis and optimization conference. Victoria (British Columbia, Canada Toronto, Ontario, Canada): University of Toronto Institute for Aerospace Studies; 2008.

23. Lewandowski W. Proekologiczne odnawialne źródła energii. WNT, Warszawa 2010.

24. Maki K, Sbragio R, Vlahopoulos N. System design of a wind turbine using a multi-level optimization approach. Renew Energy 2012;43:101-10.

25. Manwell JF, McGowan JG, Rogers AL. Wind energy explained, 1st ed. Amherst, USA: Wiley; 2002.

26. National Instruments, http//:www.sine.ni.com.

27. Ning A, Damiani R, Moriarty P. Objectives and constraints for wind turbine optimization. In: 31 st ASME wind energy symposium; 2013.

28. Świsulski D. Komputerowa technika pomiarowa. Oprogramowanie wirtualnych przyrządów pomiarowych w LabView. Agenda Wydawnicza PAK, Warszawa 2005.

29. Sandra Eriksson, Hans Bernhoff, Mats Leijon. Evaluation of different turbine concepts for wind power. Renewable and Sustainable Energy Reviews 12 (2008) 1419-1434.

30. Travis J. LabView for Everyone. Prentice-Hall, Upper Saddle River 2002.

31. Wendeker M, Kamiński Z, Czyż Z. Urząd Patentowy RP nr: P.402214, 2012.

32. Wolańczyk F. Elektrownie wiatrowe, Wydawnictwo KaBe, Krosno 2009.

33. Wood D. Small wind Turbines- Analysis, design and Application, Springer- Verlag London Limited 2011.

34. Xudong W, Shen WZ, Zhu WJ, Sorensen JN, Jin C. Blade optimization for wind turbines. In: European wind energy conference \& exhibition EWEC; 2009.

35. Xudong W, Shen WZ, Zhu WJ, Sorensen JN, Jin C. Shape optimization of wind turbine blades. Wind Energy 2009; 12:781-803. 